Indonesian Journal of Islamic Psychology

Volume 1. Number 2, December 2019 (p-ISSN: 2685-1482 e-ISSN 2714-7576)

website: http://e-journal.iainsalatiga.ac.id/index.php/ijip/index

\title{
Peningkatan Sense of Humor untuk Menurunkan Kecemasan pada Lansia
}

\author{
Retna Febri Arifiati ${ }^{*}$, Endang Sri Wahyuni ${ }^{2}$ \\ 1,2 Politeknik Kesehatan Surakarta, Indonesia
}

\begin{abstract}
The Sense of humor is an activity that uses the stimulus to stimulate happy, happy expressions in the elderly. This study aims to determine the increase in sense of humor to reduce anxiety. The study was conducted in the elderly at the Posonandu Bolon Colomadu Karanganyar. The design of this study uses crosssectional analytics. The sampling technique uses total sampling. The data collection tool in the form of an anxiety questionnaire using the Hamilton Anxiety Rating Scale (HARS) consists of 14 items. The data analysis technique used is the Pearson Product Moment correlation technique. The results of the research are that sense of humor has a role to lower elderly anxiety levels. Therefore, for an easy-to-worry elderly can begin to develop a sense of humor as one way of overcoming anxiety in the face of a mood that tends to suppress.
\end{abstract}

Keywords: anxiety; sense of humor; therapeutic

\begin{abstract}
Abstrak
Sense of humor adalah kegiatan yang menggunakan rangsangan untuk ekspresi senang, gembira pada lansia. Penelitian ini bertujuan untuk mengetahui peningkatan rasa humor untuk mengurangi kecemasan. Penelitian ini dilakukan pada Lansia di Posyandu Bolon Colomadu Karanganyar. Desain penelitian ini menggunakan analitik cross sectional. Teknik sampel menggunakan total sampling. Alat pengumpulan data dalam bentuk kuesioner kecemasan menggunakan Hamilton Anxiety Rating Scale (HARS) terdiri dari 14 item. Teknik analisis data yang digunakan adalah teknik korelasi momen produk Pearson. Hasil penelitian adalah bahwa rasa humor memiliki peran untuk menurunkan tingkat kecemasan Lansia. Oleh karena itu, untuk yang mudah-untuk-khawatir tua dapat mulai mengembangkan rasa humor sebagai salah satu cara untuk mengatasi kecemasan dalam menghadapi suasana hati yang cenderung menekan.
\end{abstract}

Kata Kunci: kecemasan; rasa humor; terapeutik

\section{*Corresponding Author}

retnafebriarifiati@yahoo.com 


\section{Pendahuluan}

Menua merupakan suatu proses alami yang dihadapi manusia, tahap yang paling krusial adalah terjadi penurunan fungsi atau perubahan pada aspek biologis, aspek psikologi, aspek sosial budaya dan aspek spiritual (Hurlock, 2017). Tanda-tanda awal lansia merasakan proses menua adalah muncul perasaan sedih, cemas, kesepian, mudah tersinggung, depresi, paranoid dan demensia (Maryam, 2008).

Pada abad 21 tantangan khusus di bidang kesehatan terus meningkatnya jumlah Lansia dengan berbagai masalah degeneratif dan Penyakit Tidak Menular (PTM) seperti diabetes, hipertensi, dan gangguan kesehatan jiwa yaitu depresi, demensia, cemas, sulit tidur (insomnia). Penyakit tersebut, akan menimbulkan permasalahan yang komplek jika tidak diatasi atau dicegah, karena akan menjadi penyakit kronis dan multipatologis.

Kecemasan yang dialami Lansia cenderung pada perasaan kekhawatiran yang tidak jelas, yang berkaitan dengan perasaan tidak pasti dan tidak berdaya terhadap satu kondisi. Dikatakan kondisi karena tidak memiliki objek yang spesifik. Kecemasan pada Lansia berbeda dengan rasa takut, dimana rasa takut merupakan penilaian intelektual terhadap suatu bahaya atau kejadian yang dialami Lansia, sedangkan kecemasan adalah respon emosional Lansia terhadap penilaian dari perasaannya tersebut (Stuard, 2013).

Prevalensi ganggguan kecemasan pada Lansia adalah 5,5\%. Gangguan kecemasan yang paling sering adalah fobia yaitu 4-8\%. Gangguan kecemasan dimulai pada masa dewasa awal atau pertengahan, tetapi beberapa ada yang tampak untuk pertama kalinya setelah usia 60 tahun (Elvira \& Hadisukanto, 2013). 
Dampak dari kecemasan dapat menimbulkan respon fisiologis yaitu sistem kardiovaskuler, pernapasan, neuromuskuler, gastrointestinal, saluran perkemihan, integument (kulit), respon pada sistem perilaku, sistem kognitif dan sistem afektif (Stuart \& Sundeen, 1998). Kecemasan kronik dapat mempersulit dan mengganggu aktivitas kehidupan sehari-hari lansia (Patricia, 2008). Kecemasan pada Lansia dapat menurunkan atau menyebabkan kerusakan kognitif, serta dapat terganggunya emosi dan peran sosial. Kecemasan yang tidak sejalan dengan kehidupan, berlangsung lama dan terus menerus, dapat menimbulkan kelelahan bahkan kematian (Stuard \& Sundeen, 1998).

Upaya untuk mendorong Lansia hidup bahagia, sehat dan sejahtera salah satunya dengan memberikan pencegahan dan merawat dari masalah kesehatan terhadap perasaan kecemasannya. Upaya pencegahan tersebut bisa dilakukan dengan pemberian obat (farmakologi) atau nonfarmakologi. Terapi humor adalah salah satu terapi nonfarmakologi yang dapat mengurangi tingkat kecemasan Lansia.

\section{Association for Applied and Therapeutic Humor (AATH)} menyatakan bahwa humor menjadi intervensi terapeutik dengan cara menggunakan stimulus untuk merangsang ekspresi senang, gembira. Terapi humor dapat digunakan dalam pelayanan kesehatan, konseling, kerja sosial, pendidikan, dan relasi bisnis (Martin, 2010) rangsangan tertawa dapat menjadi terapi efektif menurunkan stres dan rasa cemas (Bennet, 1997) meningkatkan kualitas hidup (Martin \& Lefcourt, 1983). Intervensi ini dapat meningkatkan kesehatan Lansia dan sebagai pengobatan komplementer penyakit dengan memfasilitasi penyembuhan fisik, emosional, kognitif, sosial dan spiritual. 
Aktifitas humor dapat dilakukan di lapisan masyarakat, dinikmati semua umur, dan terus berkembang dalam segala jaman. Humor juga dapat dipengaruhi oleh lingkungan sosial dan kultur budaya, dimana tidak semua orang mampu memahami tawa dan humor dari lingkungan sosial dan kultur budaya yang berbeda dengan lingkungan sosial dan kultur budaya yang dimilikinya (Martin, 2010). Sense of humor mengandung muatan emosi positif dimana dapat diasosiasikan ke dalam suatu aktifitas yang dapat menurunkan tegangan (tension) serta berkurangnya perasaan cemas (anxiety), sehingga akan menyebabkan fleksibilitas Lansia dalam berpikir, dibutuhkan Lansia melihat kemungkinan-kemungkinan memecahkan masalah yang sedang dihadapi.

Kemampuan Lansia dalam melihat berbagai kemungkinan cara memecahkan masalah adalah tanda bahwa Lansia sudah mengalami healing dalam menjalani proses terapi (Martin, 2010). Pemberian stimulus sense of humor dalam pelaksanaan terapi diperlukan kepada beberapa orang yang mengalami kesulitan untuk memulai tertawa tanpa adanya alasan yang jelas. Aktifitas tertawa termasuk stimulus yang menggunakan media untuk menimbulkan rasa humor. Kelucuan atau humor dihadirkan dari mengingat pengalaman lucu, melihat film komedi sehingga dapat menghasilkan tawa yang secara spontan, tergelitik dalam hati, tersenyum sampai pada euforia.

\section{Tujuan Sense of humor}

Humor menjadi intervensi terapeutik dengan cara menggunakan stimulus untuk merangsang ekspresi senang, gembira. Terapi humor dapat digunakan dalam pelayanan kesehatan, konseling, kerja sosial, pendidikan, dan relasi bisnis (Martin, 2010). Rangsangan tertawa dapat 
Retna Febri Arifiati, Endang Sri Wahyuni

menjadi terapi efektif menurunkan stres dan rasa cemas (Bennet, 1997). Tujuan dilakukannya penelitian ini untuk mengetahui peningkatan sense of humor untuk menurunan kecemasan Lansia, mengetahui karakteristik Lansia, mengetahui pengaruh kecemasan Lansia dengan aktifitas sense of humor di Desa Bolon Kecamatan Colomadu Kabupaten Karanganyar.

\section{Sense of humor}

Menurut Thorson dan Powell (1997) Sense of humor merupakan gabungan dari beberapa dimensi yang di dalamnya termasuk kemampuan untuk membuat, mengenali, dan mengapresiasikan humor yang membuat seseorang tertawa ataupun tersenyum dan menimbulkan kesenangan sebagai mekanisme coping serta untuk mencapai tujuan sosial. Thorson dan Powell (1997) menyatakan empat aspek penting sense of humor, yang terdiri dari a). Humor Production yaitu kemampuan untuk menemukan sesuatu yang membuat seseorang tertawa dan menimbulkan kesenangan pada setiap peristiwa dan berhubungan dengan perasaan diterima oleh lingkungan, b). Coping with Humor yaitu individu menggunakan sesuatu yang membuat seseorang bisa tertawa dan menimbulkan kesenangan untuk mengatasi emosional dan situasi yang mengandung stressful pada individu, c). Humor Appreciation yaitu kemampuan untuk mengapresiasikan sesuatu yang membuat seseorang tertawa dan menimbulkan kesenangan yang dihubungkan dengan internal locus of control seseorang, sebuah indikasi dari seberapa banyak individu mempersepsikan setiap peristiwa lucu sebagai bagian dari perilaku orang lain, d). Attitude Toward Humor yaitu kecenderungan untuk tertawa pada setiap situasi yang lucu.

Menurut Deshefy dan Longhi (2004) dimensi sense of humor terbagi atas 4 dimensi yaitu a). Survival Humor yaitu humor yang 
digunakan ketika seseorang atau sekelompok orang harus beradaptasi pada kondisi yang jarang dihadapi, bersifat ekstrim, atau yang mengandung ancaman, b). Bonding Humor yaitu humor yang digunakan untuk membentuk ikatan/hubungan diantara individu, c). Celebatory Humor yaitu humor yang digunakan ketika mengalami suka cita atau kesenangan dan ingin membaginya dengan orang lain, d). Coping Humor yaitu humor yang digunakan untuk mengatur situasi atau kejadian mengancam yang menciptakan stres dan ketegangan.

\section{Fungsi Sense of humor}

Sense of humor berperan dalam kehidupan sehari-hari. Hal ini dapat dilihat dari fungsi yang diberikan humor. Nilsen (dalam Munandar, 1996) membagi humor menjadi empat fungsi yaitu: a). Fungsi fisiologik yaitu humor yang dapat mengalihkan susunan kimia internal seseorang dan mempunyai akibat yang sangat besar terhadap sistem tubuh seseorang, termasuk sistem saraf, peredaran darah, endokrin, dan sistem kekebalan, b). Fungsi psikologik yaitu humor yang efektif menolong seseorang menghadapi kesukaran. Kemampuan untuk melihat humor dalam suatu situasi merupakan salah satu yang dapat digunakan untuk mengatasi krisis dalam hidup, sebagai perlindungan terhadap perubahan, c). Fungsi pendidikan yaitu humor yang menyebabkan seseorang lebih waspada. Oleh karena itu humor merupakan alat belajar yang penting dan sangat efektif untuk membawa seseorang agar mendengarkan pembicaraaan dan merupakan alat persuasi yang baik, d). Fungsi Sosial yaitu humor yang tidak saja dapat digunakan untuk mengikat seseorang atau kelompok yang disukai tetapi juga dapat menjauhkan seseorang dari orang atau kelompok yang tidak disukai. 
Keuntungan Aktivitas Sense of humor

Menurut Martin (2010), sense of humor mengandung banyak keuntungan. Individu dengan sense of humor yang lebih tinggi, lebih termotivasi, lebih ceria, dapat dipercaya dan mempunyai harga diri yang lebih tinggi. Kelly (2002) menyatakan bahwasanya salah satu keuntungan terbesar dengan memiliki sense of humor adalah pengaruhnya pada kesehatan salah satunya; 1). Humor bisa meningkatkan hubungan sosial, yang mana ini bisa berdampak meningkatkan kesehatan, 2). Humor mempunyai efek secara tidak langsung pada tingkat stress, 3). Proses fisiologi yang dipengaruhi oleh humor, contohnya tertawa bisa mengurangi ketegangan saraf.

\section{Lansia}

Menua pada Lansia adalah proses menurunnya kemampuan jaringan untuk memperbaiki diri atau mengganti dan mempertahankan fungsi fisiologis tubuh sehingga tidak dapat bertahan terhadap infeksi dan memperbaiki kerusakan yang di derita. Seiring dengan proses menua tersebut, tubuh akan mengalami berbagai masalah kesehatan atau yang biasa disebut sebagai penyakit degeneratif. Usia lanjut dikatakan sebagai tahap akhir perkembangan pada daur kehidupan manusia (Nugroho, 2012).

Klasifikasi WHO dalam Kemenkes RI mempunyai batasan usia lanjut yaitu middle atau young elderly usia antara 45-59 tahun, elderly usia antara 60-74 tahun, old usia antara 75-90 tahun dan dikatakan very old berusia di atas 90 tahun. Masalah yang kerap muncul pada usia lanjut, yang disebutnya sebagai a series of I's meliputi immobility (mobilisasi), instability (instabilitas dan jatuh), incontinence (inkontinesia), intellectual impairment (gangguan intelektual), infection 
(infeksi), impairment of vvision and hearig (gangguan pengelihatan dan pendengaran), isolation (depresi), inanition (malnutrisi), insomnia (gangguan tidur), hingga immune deficiency (menurunnya kekebalan tubuh) (Sari, 2010).

Bentuk permasalahan yang dihadapi Lansia adalah a). Demensia adalah suatu gangguan intelektual atau daya ingat umumnya progresif dan ireversibel. Biasanya ini sering terjadi orang yang berusia $>65$ tahun, b). Depresi merupakan hal yang terpenting dalam problem Lansia. Usia bukan merupakan faktor untuk menjadi depresi tetapi suatu keadaan penyakit medis kronis dan masalah-masalah yang dihadapi Lansia yang membuat mereka depresi. Gejala depresi pada Lansia dengan orang dewasa muda berbeda dimana pada Lansia terdapat kelsomatik, c). Skizofrenia biasanya dimulai pada masa remaja akhir atau dewasa, muda dan menetap seumur hidup. Wanita lebih sering menderita Skizofrenia lebih lambat dibanding pria. Perbedaan onset lambat adalah adanya skizofrenia paranoid pada tipe onset, d). Gangguan delusi onset usia pada gangguan delusi adalah antara 40 sampai 55 tahun, tetapi dapat terjadi kapan saja. Pada gangguan delusi terdapat waham yang sering muncul yaitu: waham kejar dan waham somatik, e). Gangguan kecemasan adalah berupa gangguan panik, fobia, gangguan obsesif konfulsif, gangguan kecemasan umum, gangguan stress akut, gangguan stres paska traumatik. Onset awal gangguan panik pada Lansia adalah jarang, tetapi dapat terjadi. Tanda dan gejala fobia pada Lansia kurang serius daripada dewasa muda, tetapi efeknya sama, jika tidak lebih, menimbulkan debilitasi pada pasien lanjut usia. Teori eksistensial menjelaskan kecemasan tidak terdapat stimulus yang dapat diidentifikasi secara spesifik bagi perasaan yang cemas secara kronis, kecemasan yang tersering pada Lansia adalah tentang kematiannya. 
Lansia mungkin berpikir menghadapi kematian dengan rasa putus asa dan kecemasan, bukan dengan ketenangan hati dan rasa integritas. Kerapuhan system saraf anotomik yang berperan dalam perkembangan kecemasan setelah suatu stressor yang berat. Gangguan stres lebih sering pada Lansia terutama jenis stres paska traumatik karena pada Lansiaakan mudah terbentuk suatu cacat fisik, f). Gangguan Somatiform ditandai gejala yang sering ditemukan pada pasien usia $>60$ tahun. Gangguan biasanya kronis dan prognosis. Untuk mententramkan pasien perlu dilakukan permeriksaan fisik berulang sehingga Lansia merasa yakin bahwa mereka tidak memiliki penyakit yang mematikan. Terapi pada gangguan ini dengan pendekatan psikologis dan farmakologis, g). Gangguan penggunaan alkohol dan zat lain yaitu riwayat minum atau ketergantungan alkohol biasanya memberikan riwayat minum berlebihan yang dimulai pada masa remaja atau dewasa. Mereka biasanya memiliki penyakit hati. Sejumlah Lansia yang memiliki riwayat mengkonsumsi alkohol pada masa remaja terdapat penyakit demensia kronis seperti ensefalopati wernicke dan sindroma korsakoff, h). Gangguan tidur pada usia lanjut adalah faktor tumggal yang paling sering berhubungan dengan peningkatan prevalensi gangguan tidur.

\section{Kecemasan}

Kecemasan adalah rasa khawatir, takut yang tidak jelas sebabnya. Kecemasan merupakan kekuatan besar dalam menggerakkan tingkah laku, baik tingkah laku yang menyimpang ataupun yang terganggu. Kedua-duanya merupakan pernyataan, penampilan, penjelmaan dari pertahanan terhadap kecemasan tersebut (Gunarsa, 2008). Kecemasan adalah suatu perasaan yang sifatnya umum, dimana Lansia merasa 
ketakutan atau kehilangan rasa kepercayaan diri yang tidak jelas baik asal maupun wujudnya (Wiramihardja, 2005).

Gejala kecemasan yang bersifat fisik diantaranya jari tangan dingin, detak jantung makin cepat, berkeringat dingin, kepala pusing, nafsu makan berkurang, tidur tidak nyenyak, dada sesak. Sedangkan gejala yang bersifat mental adalah ketakutan merasa akan ditimpa bahaya, tidak dapat memusatkan perhatian, tidak tenteram, ingin lari dari kenyataan (Sundari, 2004).

Jeffrey S, Spencer A, dan Beverly (2005) mengklasifikasikan gejala kecemasan dalam tiga jenis diantaranya a). Gejala fisik dari kecemasan yaitu kegelisahan, anggota tubuh bergetar, banyak berkeringat, sulit bernafas, jantung berdetak kencang, merasa lemas, panas dingin, mudah marah atau tersinggung, b). Gejala behavioral dari kecemasan yaitu berperilaku menghindar, terguncang, melekat dan dependen, c). Gejala kognitif dari kecemasan yaitu khawatir tentang sesuatu, perasaan terganggu akan ketakutan terhadap sesuatu yang terjadi di masa depan, keyakinan bahwa sesuatu yang menakutkan akan segera terjadi, ketakutan akan ketidakmampuan untuk mengatasi masalah, pikiran terasa bercampur aduk atau kebingungan, sulit berkonsentrasi.

\section{Faktor-faktor Penyebab Kecemasan}

Kecemasan sering kali berkembang selama jangka waktu tertentu dan sebagian besar tergantung pada pengalaman hidup Lansia. Peristiwa atau situasi khusus dapat mempercepat munculnya serangan kecemasan. Menurut Savitri (2003) ada beberapa faktor yang menunjukkan reaksi kecemasan, diantaranya yaitu a). Lingkungan atau sekitar tempat tinggal Lansia sangat mempengaruhi cara berfikirnya tentang diri sendiri maupun orang lain. Hal ini disebabkan karena 
adanya pengalaman Lansia yang tidak menyenangkan dengan keluarga, sahabat, ataupun dengan rekan kerja, sehingga Lansia merasa tidak aman terhadap lingkungannya, b). Emosi yang ditekan, kecemasan bisa terjadi jika Lansia merasa tidak mampu menemukan jalan keluar untuk perasaannya sendiri dalam hubungan personal, terutama jika dirinya menekan rasa marah atau frustasi dalam jangka waktu yang sangat lama, c). Sebab fisik, pikiran dan tubuh senantiasa saling berinteraksi dan dapat menyebabkan timbulnya kecemasan. Hal ini terlihat dalam kondisi seperti misalnya kehamilan, semasa remaja dan sewaktu pulih dari suatu penyakit. Selama ditimpa kondisi-kondisi ini, perubahan emosi lazim muncul, dan ini dapat menyebabkan timbulnya kecemasan.

Daradjat (dalam Rochman, 2010) mengemukakan beberapa penyebab dari kecemasan yaitu a). Rasa cemas yang timbul akibat ada bahaya yang mengancam dirinya. Kecemasan ini lebih dekat dengan rasa takut, karena sumbernya terlihat jelas di dalam pikiran, b). Cemas karena merasa berdosa atau bersalah, karena melakukan hal yang berlawanan dengan keyakinan atau hati nurani. Kecemasan ini sering menyertai gejala gangguan mental, yang kadang-kadang terlihat dalam bentuk umum, c). Kecemasan yang berupa penyakit dan terlihat dalam beberapa bentuk. Kecemasan ini disebabkan oleh hal yang tidak jelas dan tidak berhubungan dengan apapun yang terkadang disertai dengan perasaan takut yang mempengaruhi pribadi Lansia. Kecemasan hadir karena adanya suatu emosi yang berlebihan.

Selain itu karena faktor lingkungan yang menyertai baik lingkungan keluarga, sekolah. Sementara itu Az-Zahrani (2005) menyebutkan faktor yang mempengaruhi adanya kecemasan yaitu a). Lingkungan keluarga dimana keadaan rumah dengan kondisi sering terjadi pertengkaran atau kesalah pahaman serta adanya 
ketidakpedulian anak terhadap Lansia, dapat menyebabkan ketidaknyamanan serta kecemasan pada Lansia saat berada di rumah, b). Lingkungan Sosial adalah salah satu faktor yang dapat mempengaruhi kecemasan. Jika Lansia berada pada lingkungan yang tidak baik menimbulkan suatu perilaku yang buruk, yang akan memberikan penilaian buruk di masyarakat. Kecemasan muncul karena adanya ancaman atau bahaya yang tidak nyata dan sewaktu-waktu terjadi pada Lansia, menyebabkan penolakan dari masyarakat sehingga menyebabkan Lansia merasa cemas berada di lingkungan yang baru dihadapi (Patotisuro, 2004).

Sedangkan Page (dalam Rufaidah, 2009) menyatakan faktor-faktor yang mempengaruhi kecemasan adalah a). Faktor fisik dapat melemahkan kondisi mental Lansia sehingga memudahkan timbulnya kecemasan, b). Trauma atau konflik munculnya gejala kecemasan sangat bergantung pada kondisi Lansia, dalam arti bahwa pengalaman emosional atau konflik mental yang terjadi pada Lansia akan memudahkan timbulnya gejala-gejala kecemasan, c). Lingkungan awal yang tidak baik adalah faktor utama yang dapat mempengaruhi kecemasan Lansia, jika faktor tersebut kurang baik maka akan menghalangi pembentukan kepribadian dan muncul gejala kecemasan.

Yustinus (2006) membagi beberapa dampak dari kecemasan ke dalam beberapa simtom, antara lain a). Simtom suasana hati dimana individu yang mengalami kecemasan memiliki perasaan akan adanya hukuman dan bencana yang mengancam dari suatu sumber tertentu yang tidak diketahui. Orang yang mengalami kecemasan tidak bisa tidur, dan dengan demikian dapat menyebabkan sifat mudah marah, b). Simtom kognitif yaitu kecemasan dapat menyebabkan kekhawatiran dan keprihatinan pada Lansia mengenai hal yang tidak menyenangkan yang 
mungkin terjadi. Individu tersebut tidak memperhatikan masalah yang ada, sehingga individu sering tidak bekerja atau belajar secara efektif, dan akhimya akan menjadi lebih merasa cemas, c). Simtom motor dimana orang-orang yang mengalami kecemasan sering merasa tidak tenang, gugup, kegiatan motorik menjadi tanpa arti dan tujuan, misalnya jari kaki mengetuk-ngetuk, dan sangat kaget terhadap suara yang terjadi secara tiba-tiba. Simtom motor merupakan gambaran rangsangan kognitif yang tinggi pada Lansia dan merupakan usaha untuk melindungi dirinya dari apa saja yang dirasanya mengancam.

\section{Metodologi Penelitian}

Desain penelitian yang digunakan adalah deskriptif korelasi yaitu penelitian yang diarahkan mencari pengaruh antara variabel independen yaitu Sense of humor dan dependen yaitu kecemasan. Pendekataan yang digunakan cross sectional, yaitu dimana peneliti melakukan pengumpulan data baik dari variabel independen maupun variabel dependen dilakukan secara bersama-sama (Notoatmodjo, 2005).

Populasi menurut Sugiono (2007) adalah wilayah generalisasi yang terdiri atas objek atau subjek yang mempunyai kuantitas dan karateristik tertentu yang ditetapkan oleh peneliti untuk mempelajari dan kemudian ditarik kesimpulannya. Populasi dalam penelitian ini adalah seluruh anggota posyandu Lansia Desa Bolon Kecamatan Colomadu Kabupaten Karanganyar. Tehnik sampel yang digunakan pada penelitian ini adalah total sampling yaitu tehnik penentuan sampel bila semua anggota populasi digunakan sebagian sampel (Sugiono, 2002). Lansia yang digunakan adalah Lansia yang ada di Desa Bolon Kecamatan Colomadu Karanganyar. 
Alat yang digunakan untuk mengukur variabel kecemasan pada Lansia adalah kuesioner. Kuesioner dalam penelitian ini terdiri dari beberapa pertanyaan yang digunakan untuk memperoleh informasi responden. Metode pengumpulan data adalah suatu usaha untuk memperoleh data dengan ditentukan untuk peneliti (Arikunto, 2006). Pengumpulan data dalam penelitian ini menggunakan metode wawancara yaitu sebuah dialog yang dilakukan oleh Peneliti untuk memperoleh informasi dari Lansia (Sugiono, 2007). Dalam hal ini peneliti menggunakan wawancara terstruktur yaitu wawancara yang sudah ada panduannya berupa pertanyaan yang telah disusun sesuai kebutuhan peneliti (Wasis, 2008).

\section{Analisis Data}

\section{Univariat}

Analisis univariat adalah analisis yang digunakan untuk menganalisis tiap variabel dari hasil penelitian (Notoatmodjo, 2005). Penelitian melakukan analisis univariat dengan tujuan yaitu analisis diskriptif variabel penelitian berdasarkan karakteristik dan tingkat kecemasan pada Lansia.

\section{Analisis Bivariat}

Analisis bivariat dilakukan dengan tujuan untuk menguji variabelvariabel penelitian yaitu variabel bebas dan variabel terikat. Hal ini digunakan untuk membuktikan hipotesis yang telah dibuat (Notoatmodjo, 2005). Sebelum dilakukan analisis bivariat data terlebih dahulu diuji kenormalanya dengan menggunakan Kolmogorov-Smirnov tes dengan derajat kemaknaan $\alpha=0.05$. Hasil uji kenormalan pada data pre kecemasan bahwa p-value 0,541 $(>0,05)$, dengan demikian maka 
data berdistribusi normal, dan Hasil uji kenormalan pada data post kecemasan bahwa p-value 0,403 $(>0,05)$ maka uji yang digunakan adalah korelasi Pearson Product Moment, menggunakan uji Rank Spearman. Jika data berjenis katagorik maka uji yang digunakan adalah Chi-Square.

\section{Hasil Penelitian dan Pembahasan}

Pada bagian ini diberikan gambaran dari partisipan. Gambaran partisipan ini pertama adalah berdasarkan jenis kelamin. Berdasarkan data yang diperoleh mengenai jenis kelamin partisipan, jumlah laki-laki sejumlah 33 orang subyek (41.3\%) dan perempuan sebanyak 47 orang (58.8\%). Untuk lebih jelasnya dapat dilihat pada Tabel 1.

\begin{tabular}{|c|c|c|c|c|c|}
\hline & & Frequency & Percent & $\begin{array}{c}\text { Valid } \\
\text { Percent } \\
\end{array}$ & $\begin{array}{c}\text { Cumulative } \\
\text { Percent }\end{array}$ \\
\hline \multirow{3}{*}{ Valid } & $\mathrm{L}$ & 33 & 41.3 & 41.3 & 41.3 \\
\hline & $P$ & 47 & 58.8 & 58.8 & 100.0 \\
\hline & Total & 80 & 100.0 & 100.0 & \\
\hline
\end{tabular}

Gambaran partisipan ini kedua adalah berdasarkan usia. Berdasarkan data yang diperoleh mengenai usia partisipan, usia 60-74 tahun sejumlah 67 orang subyek (83.8\%) dan usia 75-90 tahun sebanyak 13 orang subyek (16.3\%). Untuk lebih jelasnya dapat dilihat pada Tabel 2.

Tabel 2. Gambaran partisipan berdasarkan usia

\begin{tabular}{|c|c|c|c|c|c|}
\hline & & Frequency & Percent & $\begin{array}{c}\text { Valid } \\
\text { Percent }\end{array}$ & $\begin{array}{c}\text { Cumulative } \\
\text { Percent }\end{array}$ \\
\hline \multirow{3}{*}{ Valid } & 60 - 74 tahun & 67 & 83.8 & 83.8 & 83.8 \\
\hline & 75 - 90 tahun & 13 & 16.3 & 16.3 & 100.0 \\
\hline & Total & 80 & 100.0 & 100.0 & \\
\hline
\end{tabular}

Gambaran partisipan ini ketiga adalah berdasarkan riwayat pengobatan. Berdasarkan data yang diperoleh mengenai lansia yang rutin mengkonsumsi obat dan berobat karena riwayat penyakit tertentu 
sebanyak 50 subyek $(62,5 \%)$ dan lansia yang tidak melakukan rutin berobat sebanyak 30 orang subyek (37.5\%). Untuk lebih jelasnya dapat dilihat pada Tabel 3.

Tabel 3. Gambaran partisipan berdasarkan riwayat

\begin{tabular}{rlrrrr}
\multicolumn{6}{c}{ pengobatan } \\
\hline \hline \multirow{4}{*}{ Valid } & Frequency & Percent & $\begin{array}{c}\text { Valid } \\
\text { Percent }\end{array}$ & $\begin{array}{c}\text { Cumulative } \\
\text { Percent }\end{array}$ \\
\cline { 3 - 6 } & Ya & 50 & 62.5 & 62.5 & 62.5 \\
& Tidak & 30 & 37.5 & 37.5 & 100.0 \\
& Total & 80 & 100.0 & 100.0 & \\
\hline \hline
\end{tabular}

\section{Analisis Uji Prasyarat}

Analisis uji prasyarat digunakan untuk mengetahui apakah data berdistribusi normal atau tidak sehingga dapat ditentukan metode analisis yang sesuai. Hasil analisis uji prasyarat menggunakan uji Shapiro Wilk (data $\leq 80$ ) dan didapatkan nilai $\rho>0,05$ sehingga dapat disimpulkan data berdistribusi normal. Karena berdistribusi normal maka analisis statistik yang akan digunakan uji t berpasangan. Hasil perhitungan normalitas data dalam penelitian ini disajikan dalam tabel 4.

Tabel 4. Uji Normalitas variabel kecemasan

\begin{tabular}{llrr}
\hline \hline & & $\begin{array}{c}\text { Skor Kecemasan } \\
\text { Pre }\end{array}$ & $\begin{array}{c}\text { Skor Kecemasan } \\
\text { Post }\end{array}$ \\
\hline $\mathrm{N}$ & & 80 & 80 \\
\multirow{2}{*}{ Normal Parameters } & & & \\
& Mean & 21.69 & 19.89 \\
& Std. Deviation & 5.720 & 4.661 \\
Most Extreme Differences & Absolute & .090 & .100 \\
& Positive & .073 & .070 \\
Kolmogorov-Smirnov Z & Negative & -.090 & -.100 \\
Asymp. Sig. (2-tailed) & & .802 & .893 \\
\hline \hline
\end{tabular}




\section{Analisis Uji Hipotesa}

Hipotesis pada penelitian ini adalah ada pengaruh antara sense of humor dengan kecemasan Lansia. Hipotesis alternative diterima apabila terdapat jumlah signifikan lebih kecil dari 0,05. Dari perhitungan hasil analisis uji t berpasangan diperoleh $\rho=0,000$ dimana $\rho<0,05$, dapat disimpulkan bahwa ada pengaruh pemberian aktivitas sense of humor terhadap kecemasan Lansia di Posyandu Bolon Colomadu karanganyar.

\section{Pembahasan}

Dalam kesehariannya, ada banyak pekerjaan, tantangan dan tuntutan yang harus dijalankan oleh Lansia. Berbagai hal dan situasi juga dapat mempengaruhi keberhasilan atau justru menghambat Lansia. Para Lansia dapat mengendalikan ketegangan dan tetap tenang dalam beraktivitas.

Kecemasan adalah perasaan ketakutan (baik realistis maupun tidak realistis) yang disertai dengan keadaan peningkatan reaksi kejiwaan. Kecemasan merupakan bagian dari tiap pribadi manusia terutama jika individu dihadapkan pada situasi yang tidak jelas dan tidak menentu, sehingga kecemasan juga dapat meningkatkan kesiapan diri seseorang dalam menghadapi suatu tantangan. Sebagian besar dari individu merasa cemas dan tegang jika menghadapi situasi yang mengancam atau stressor.

Kecemasan dianggap abnormal jika kecemasan itu terjadi dalam situasi yang dapat diatasi dengan sedikit kesulitan oleh kebanyakan orang. Artinya, jika kebanyakan orang lain dapat mengatasi suatu kesulitan yang sama dengan lebih mudah, sedangkan seseorang merasakan kesulitan itu sebagai masalah yang sangat besar yang dirasa membuat dirinya tidak mampu untuk mengatasinya. 
Menurut Cattell, Scheier dan Spielberger (dalam Zulkarnain \& Novliadi, 2009) menggambarkan kecemasan sebagai state anxiety dan trait anxiety. State anxiety adalah reaksi emosi sementara yang timbul pada situasi tertentu, yang dirasakan sebagai suatu ancaman, keadaan ini ditentukan oleh perasaan ketegangan yang subyektif. Sedangkan trait anxiety adalah ciri atau sifat seseorang yang cukup stabil yang mengarahkan seseorang untuk menginterpretasikan suatu keadaan sebagai ancaman. Orang yang memiliki trait anxiety tinggi akan memiliki state anxiety yang tinggi pula.

Kelvens (1997) menyatakan bahwa baik state dan trait anxiety berhubungan dengan kepribadian seseorang. Dalam hal ini, seseorang yang cemas karena faktor state anxiety dapat dikatakan berhubungan dengan kepribadiannya yang cemas. Begitu juga dengan seseorang yang cemas karena faktor trait anxiety akan memiliki kecemasan yang berhubungan dengan kepribadiannya.

Menurut Endler dan Hunt (dalam Calhoun \& Acocella, 1995) kecemasan bukan saja bergantung pada "variabel manusianya" tapi juga rangsang yang membangkitkan kecemasan. Menurut Djiwandono (2000), timbulnya kecemasan yang paling besar pada lansia disebabkan karena psikis dan tekanan dalam hidup. Reaksi cemas yang hebat berlangsung selama bertahun-tahun sehingga memberikan dampak pada kesulitan tidur (insomnia). Biasanya mereka permasalahan hidup, penyakit yang tidak tertangani dengan baik menjadi mimpi buruk yang sangat menakutkan, jika memikirkan akan memunculkan reaksi perut menjadi sakit, gelisah, menggigil, berkeringat dan sering ke kamar kecil, mudah merasa panik dan tidak bisa berkonsentrasi.

Ada berbagai cara yang dapat dilakukan oleh seseorang dalam mengatasi tekanan dan rasa cemas. Salah satu cara yang dipakai adalah 
dengan mengembangkan sense of humor. Menurut Gomes (dalam Zulkarnain \& Novliadi, 2009), dengan sense of humor dapat menimbulkan refleks tertawa, dan tertawa merupakan obat terbaik untuk melawan stres. Untuk dapat mengamati, merasakan, atau mengungkapkan humor, seseorang memerlukan kepekaan terhadap rasa humor (sense of humor).

Seseorang yang peka terhadap rasa humor (sense of humor) mengandung banyak keuntungan. Lansia yang memiliki sense of humor yang lebih tinggi, lebih termotivasi, lebih ceria, dapat dipercaya dan mempunyai self-esteem yang lebih tinggi. Salah satu keuntungan yang terbesar dengan memiliki kepekaan terhadap humor (sense of humor) adalah pengaruhnya pada kesehatan. Martin (2001) membagi sense of humor menjadi tiga tingkatan; Pertama, humor bisa menjadi perantara hubungan sosial, yang mana ini bisa menciptakan health-enhancing effects (efek meningkatkan kesehatan); Kedua, humor mempunyai efek secara tidak langsung pada tingkatan stres. Seseorang yang peka terhadap humor dalam kehidupan, pengalaman stressful individu sering diminimalkan, Ketiga, proses fisiologi yang dipengaruhi oleh humor. Sebagai contoh, tertawa bisa mengurangi ketegangan saraf.

Menurut Ancok (1996), ada studi yang mempelajari bahwa humor dapat menimbulkan gairah baru. Di sisi lain, humor juga berfungsi untuk menghilangkan kecemasan sekaligus alat kontrol sosial. Sedangkan menurut Caprio (1996) menyatakan bahwa humor yang identik dengan senyum dapat membuat orang lebih merasa enak humor bisa melepaskan orang dari rasa tertekan, membuat otot-otot wajah terasa rileks, dan membuat jiwa seseorang menjadi lebih hidup. Sejumlah pakar mengatakan bahwa humor bukan semata-mata berisi lelucon konyol yang diikuti tawa terpingkal-pingkal. Tetapi humor lebih merupakan 
suatu cara melihat, bereaksi dan berinteraksi terhadap dunia. Bahkan keahlian dalam mengemas humor menjadi ciri utama bagi mereka yang sukses, kreatif, dan sehat.

Dalam sebuah penelitian, para peneliti menemukan tertawa dapat meningkatkan sistem kekebalan sampai 40 persen. Tertawa merangsang peredaran darah, menstabilkan tekanan darah, meningkatkan pemberian oksigen pada darah, memperlancar pencernaan, dan memijat organ-organ tubuh yang penting. Bahkan akhir-akhir ini telah terbukti bahwa tertawa itu menolong tubuh untuk mengatasi rasa nyeri yang kronis.

Tertawa juga merupakan obat, yang hebat untuk kerohanian. Tertawa itu juga meningkatkan kesenangan seseorang untuk terus hidup, mengurangi tekanan dan rasa cemas, serta memperlancar hubungan antar pribadi. Oleh karena itu para profesional kesehatan merasa yakin sebaiknya memandang serius humor sebagai sebuah terapi. Menurut Bennett (1997), bukti ini akan menjadi penting secara klinis. Pemakaian humor untuk merangsang tertawa dapat menjadi terapi efektif menurunkan stres dan rasa cemas. Sejalan dengan itu, menurut Gomes (dalam Zulkarnain \& Novliadi, 2009) humor memang menimbulkan refleks tawa, dan tertawa merupakan obat terbaik untuk melawan persaan cemas dan tertekan. Pendapat ini juga didukung oleh hasil penelitian Hasanat (1996) yang menyatakan bahwa senyum merupakan bentuk tawa yang ringan yang dapat untuk mampu mengurangi tingkat ketegangan yang dialami seseorang.

Hasil penelitian menunjukan bahwa ada hubungan negatif antara sense of humor dengan kecemasan $(\mathrm{r}=-0.275 \mathrm{p}<0.01)$. Hal ini mengindikasikan semakin tinggi tinggi sense of humor seseorang maka semakin rendah tingkat kecemasannya. Hasil penelitian ini sesuai 
dengan penelitian Yovetick, Dale dan Hudak (1990) yang menemukan bahwa individu yang sense of humor tinggi dilaporkan hanya sedikit merasakan kecemasan daripada individu yang memiliki Sense of humor yang rendah ketika dihadapkan pada situasi cemas.

Menurut Atkinson dkk (1996), salah satu cara utama untuk menanggulangi kecemasan adalah dengan menitikberatkan pada emosinya, yaitu individu berusaha mereduksi perasaan cemas melalui berbagai macam cara. Ada berbagai cara yang dapat dilakukan oleh seseorang dalam mengatasi tekanan dalam menghadapi suasana. Salah satu cara yang dipakai adalah dengan mengembangkan sense of humor. Berkaitan dengan hal tersebut, beberapa penelitian telah mendokumentasikan fakta bahwa sense of humor yang moderate mengurangi perasaan negatif atau yang tidak menyenangkan pada saat berhadapan dengan situasi yang mengancam.

Penelitian yang dilakukan Friedman, dkk (2002) mengatakan humor sangat diperlukan oleh seseorang. Hal ini dikarenakan pada saat mereka dalam kondisi tertekan seperti memikirkan masalah kehidupan dan kesehatan. Selain itu, penelitian yang dilakukan oleh Brown dan Keegan (1999) juga menemukan bahwa sense of humor dapat mengurangi stres moderate, kecemasan dan membantu individu untuk dapat mengatasi masalah dengan lebih baik.

Martin (2003) mengatakan bahwa melalui humor seseorang dapat menjauhkan diri dari situasi yang mengancam dan memandang masalah dari sudut kelucuan untuk mengurangi kecemasan dan rasa tidak berdaya. Menurut Thorson dan Powell (1993), individu yang memiliki perilaku yang mengarah pada humor dikorelasikan berhubungan positif dengan kemampuan sosial dan psikologi yang bervariasi. Berdasarkan hasil penelitiannya ditemukan bahwa orang yang memiliki sense of 
humor memiliki karakteristik kepribadian sebagai berikut: menonjolkan diri (exhibition), dominan (dominance), memiliki kepribadian yang hangat (warmth), asertif (assertiveness), terlihat selalu gembira (excitement seeking), mampu membangkitkan emosi positif (arousability positive emotions), kecenderungan untuk mengarahkan kepribadian lebih banyak keluar daripada ke dalam diri sendiri dan lebih ceria (etraversion and cheerfulness). Selain itu, sense of humor juga berkorelasi negatif dengan neurotisme (neuroticism), pesimis (pessimism), menghindar (avoidance), self-esteem yang negatif (negative self-esteem), agresi (aggression), depresi (depression), dan mood yang buruk (bad mood). Berdasarkan analisis tambahan, diperoleh hasil bahwa usia ikut mempengaruhi kecemasan seseorang.

Hal ini terlihat dari nilai $(F=0,854 \mathrm{p}<0.01)$. Sehingga dapat disimpulkan bahwa ada perbedaan kecemasan sangat signifikan berdasarkan usia subjek penelitian. Subjek yang berusia 60-74 tahun memiliki tingkat kecemasan yang lebih tinggi. Hasil ini sejalan dengan penelitian yang dilakukan Coleman (dalam Zulkarnain \& Novliadi, 2009) mengatakan keparahan kecemasan akan tergantung kepada usia individu, karena usia mempengaruhi cara individu dalam mengevaluasi keadaan yang menimbulkan kecemasan. Selain itu, berdasarkan jenis kelamin ditemukan adanya perbedaan kecemasan. Ini terlihat dari nilai $(\mathrm{t}=0,854 \mathrm{p}<0.05)$. Subjek yang berjenis kelamin perempuan memiliki tingkat kecemasan lebih tinggi dibandingkan subjek berjenis kelamin laki-laki. Hasil ini sejalan dengan pendapat yang dikemukakan oleh Yusuf (2009) mengatakan gangguan kecemasan memiliki prevalensi 6-7\% dari populasi umum, dimana kelompok perempuan lebih banyak jumlahnya daripada laki-laki. 
Pendapat senada dikemukakan oleh Gunadi (dalam Swasti, Helena \& Pujasari, 2013) yang mengatakan bahwa perempuan lebih peka dengan emosinya, yang pada akhirnya peka juga terhadap perasaanperasaan cemasnya. Perbedaan ini bukan hanya dipengaruhi oleh faktor emosi, tetapi juga dipengaruhi oleh faktor kognitif. Perempuan cenderung melihat hidup atau peristiwa yang dialaminya dari segi detail, sedangkan laki-laki cara berpikirnya cenderung global atau tidak detail. Individu yang melihat lebih detail, akan juga lebih mudah dirundung oleh kecemasan karena informasi yang dimiliki lebih banyak dan itu akhirnya bisa benar-benar menekan perasaannya. Hal ini sesuai dengan pernyataan Coleman (dalam Zulkarnain \& Novliadi, 2009) bahwa tingkat kecemasan tergantung pada pengalaman-pengalamannya, sehingga mempengaruhi cara individu dalam mengevaluasi keadaan yang menimbulkan kecemasan. Lansia yang memiliki pengalamanpengalaman yang lebih banyak dalam menghadapi masalah kesehatan dan kehidupan, sehingga menjadi lebih tahan terhadap tekanan-tekanan yang dialami dibandingkan dengan lansia yang tidak memiliki pengalaman mengolah emosi.

Hasil analisis data penelitian dari hasil analisis statistik dengan menggunakan korelasi pearson product moment antara variabel sense of humor dengan kecemasan diperoleh koefisien korelasi sebesar $(r=0,854$ $\mathrm{p}<0.01$ ). Kondisi ini menunjukkan bahwa ada hubungan positif, yang sangat signifikan antara sense of humor dengan kecemasan.

\section{Simpulan}

Berdasarkan hasil penelitian diketahui bahwa sense of humor memiliki peran untuk menurunkan tingkat kecemasan Lansia. Oleh karena itu bagi Lansia yang mudah cemas dapat mulai mengembangkan 
sense of humor sebagai salah satu cara untuk mengatasi rasa cemas pada saat menghadapi suasana yang cenderung menekan.

\section{Daftar Pustaka}

Aizid, R. (2011). Babat Ragam Penyakit Paling Sering Menyerang Orang Kantoran. Jakarta: Buku Kita.

Ancok, D. (1996). Humor Juga Alat Kontrol Sosial dalam Prisma No.1 Tahun XXV. Jakarta: PT Pustaka LP3ES Indonesia.

Aprilia, N. I., \& Puspitasari, N. (2007). Faktor Yang Mempengaruhi Tingkat Kecemasan Pada Wanita Perimenopause. The Indonesian Journal of Public Health, 4, (1), 35-42. https://www.neliti.com/publications/3876/faktor-yangmempengaruhi-tingkat-kecemasan-pada-wanita-perimenopause Arief, M. T. Q. (2009). Pengantar Epidemiologi Penelitian. Surakarta: UNS Press.

Atkinson, K. C., \& Benn, D. J. (1996). Penantar Psikologi Jilid II. Edisi XI. (Terjemah Kusuma, W). Jakarta: Erlangga.

Az Zahrani. (2005). Konseling Terapi. Jakarta: Gema Isani Press.

Azwar, A. (1997). Pengantar Pelayanan Dokter Keluarga. Yayasan Penerbitan Ikatan Dokter Indonesia.

. (2002). Dokter Keluarga. Direktorat Jenderal Bina Kesehatan Masyarakat Departemen Kesehatan RI.

Barbara, K. et al. (2010). Buku Ajar Fundamental Keperawatan: Konsep, Proses, Dan Praktik Edisi 7. Jakarta: EGC.

Bennet, M. (1997). The sense of humor: Explorations of a personality characteristic. Berlin: Mouton de Gruyter, 66-69 
Bennett, C. A. (1997). "The five Vs - a buyer's perspective of the marketing mix". Marketing Intelligence \& Planning, 15, (3), 151156. https://doi.org/10.1108/02634509710165957

Brown., \& Keegan. (1999). Stress women in work place. Journal of Clinical Psychology, 49, (1), 13-23.

Calhoun, F., \& Acocella, J. (1995). Psikologi Tentang Penyesuaian dan Hubungan Kemanusiaan, (edisi ketiga). Semarang: IKIP Semarang. Cano, A., et al. (2003). Family Support, Self-Rated Health, And Psychological Distress, www.Pubmed.Com. Di Akses 3 Januari 2019. Caprio. (1996). How to develop your sense of humor. Dobuque, IA: Kendal \& Hunt.

Dakota University. (2007). Psychology and Anxiety. Www.Dakota.Fmpdata.Netpsych. Di Akses 2 Januari 2019.

Dalami, E., Dkk. (2009). Asuhan Keperawatan Jiwa Dalam Masalah Psikososial. Jakarta: TIM.

Damayanti \& Purnamasari. (2011). Berfikir Positif dan Harga Diri Pada Wanita Yang Mengalami Masa Premenopause. http://www.Library.Upnvj.Ac.Id/Pdf. Diunduh Tanggal 5 Januari 2019.

Deshefy., Longhi, T., Dixon, J. K., Olsen, D., \& Grey, M. (2004). Privacy and Confidentiality Issues in Primary Care: views of advanced practice nurses and their patients. Nurs Ethics, 11, (4), 378394. http://www.ncbi.nlm.nih.gov/pubmed?term=15253573

Djiwandono. (2000). Konseling Dan Terapi dengan Anak Dan Orang Tua. Jakarta: PT. Gasindo

Elvira, S. D., \& Hadisukanto, G. (2013). Buku Ajar Psikiatri Badan. Jakarta: Penerbit FK UI. 
Felix., Dkk. (2007). Skoring Psikopatologi Dan Faktor Yang Berhubungan Pada Perempuan Usia Perimenopause. http://Mki.Idionline.Org/Index. Php?Upage=Mki_Dl\&Smod, Diunduh Tanggal 3 Januari 2019

Friedman, H.H, Friedman, W.L \& Amoo, T. (2002). Using Humor in the Introductory Statistics Course. Journal of Statistics Education, 10, (3), 234-248. http://jse.amstat.org/v10n3/friedman.html

Widya, G. (2010). Mengatasi Insomnia: Cara Mudah Mendapatkan Kembali Tidur. Jogjakarta: Katahati.

Gaol, B, P. L. (2004). Hubungan Berfikir Positif dengan Kecemasan Menghadapi Masa Bebas Pada Narapidana. Skripsi. Fakultas Psikologi-Universitas Mercu Buana.

Gunarsa, D. S. (2008). Psikologi Perawatan. Jakarta: Gunung Mulia.

Hadi, S. (2000). Statistik 2. Yogyakarta: Andi Offset.

Hardjanta, G. (2003). Efektivitas Perlakuan Intensi Paradoksal Pada

Penderita Insomnia. Psikodimensia: Kajian Ilmiah Psikologi.

Semarang: Universitas Katolik Soegijapranata. Vol.1. No. 1 (21-26).

Hasanat, N. U. (1996). Ekspresi Senyum untuk Meningkatkan Hubungan Interpersonal. Buletin Psikologi, IV, (1), 26-32. https://jurnal.ugm.ac.id/buletinpsikologi/article/view/13465/96 57

Hawari, D. (2006). Manajemen Stres, Cemas Dan Depresi. Cetakan 2, Jakarta: Balai Penerbit Fakultas Kedokteran UI.

Hawari, D. (2007). Sejahtera Di Usia Lanjut Dimensia Psikoreligi Pada Lanjut Usia (Lansia). Jakarta: Balai Penerbit FKUI.

Hediyani, N. (2012). Dampak Insomnia Bagi Kesehatan. http://www.Dokterku-Online.com Diunduh Tanggal 4 Januari 2019. 
Hidayat, A. A. (2007). Metodologi Penelitian Keperawatan Dan Teknik Analisis Data. Jakarta: Salemba Medika.

Hidayat. (2012). Hubungan Tingkat Kecemasan Dengan Kejadian Insomnia Pada Mahasiswa Pogram Studi Ilmu Keperawatan Universitas Diponegoro. http://Eprints.Undip.Ac.Id/331601/1/BAB_1.1p $\quad$ Df, Diunduh Tanggal 5 Januari 2019.

Hoeve, V. (1992). Ensiklopedi (Terjemahan Oleh Irsad, M). Jakarta: Ichtar Baru.

Hurlock. (2017). Psikologi Perkembangan. Ed 5, and. Jakarta: Penerbit Erlangga.

Ibrahim, A. S. (2012). Panik Neurosis Dan Gangguan Cemas. Tangerang: Jelajah Nusantara.

James A. T. Corresponding Author. F. C. Powell. (1997). University of to quality of life. John Wiley \& Sons, Inc. J Clin Psychol, 53, 605-619.

Jeffrey S. Nevid, J. S, Rathus, S. A \& Green, B. (2005). Psikologi Abnormal. Jilid 2. Jakarta: Erlangga.

Jumani. (2011). Hubungan Antara Kecemasan Dengan Insomnia Pada Lansia Di Kampung Amposari Kelurahan Kedungmudu Kecamatan Tembalang Semarang.

Kelvens, C. (1997). Fear and anxiety. Diundah dari: http://www.csun.edu/ vcpsy00h/students/fear.htm

Kemalasari. (2010). Penyakit yang sering terjadi pada lansia.

Keperawatan gerontik. SRIKES Kepanjen Malang.

Lanywati, E. (2001). Insomnia: Gangguan Sulit Tidur. Yogyakarta: Kanisius. 
Lao, F. L., et al. (2000). Asia Pacific Journal of Family Medicine, 5, (1): Focus on Family, http://www.Apfmj.Com/Afm5_1/Index.Htm, Di Akses 3 Januari 2019

Martin, R. A. (2001). Humor, laughter, and psysical health: Methodological issues and reseach finding. Psychological Bulletin, 127, 504-519.

Martin, R. A., \& Lefcourt, H. M. (1983). Sense. Martin, Rod A.: U Waterloo, Canada. Source. Journal of Personality and Social Psychology, Vol. $45,(6)$

Martin, R. A. (2003). Sense of humor. dalam S.J. Loperz \& C.R. Snyder, Positive psychological assessment: A handbook of models and measures. Washington, DC: American Psychological Association.

Martin, Rod A. (2010). The Psychology of Humor: An Integrative Approach. California: Elsevier Academic Press.

Maryam, S. (2008). Menengenal Usia Lanjut dan Perawatannya. Jakarta: Salemba Medika.

Murtagh, J. (1998). General Practice. 2nd Edition, The Mcgraw-Hill Companies, Inc.

Murti, B. (2007). Bahan Ajar Biostastitik Dan Epidemiologi. Semester 1 Pasca Sarjana UNS Surakarta.

Nevid, J. F., Dkk. (2005). Psikologi Abnormal. Jakarta: Erlangga.

Notoatmodjo, S. (2005). Ilmu kesehatan masyarakat. Jakarta: Rineka Cipta.

Nugroho, A. (2012). Faktor-Faktor yang Mempengaruhi Intellectul Capital Disclosure (ICD). Accounting Analysis Journal, 1, (2), 1-11. https://doi.org/10.15294/aaj.v1i2.702

Rafknowledge. (2004). Insomnia Dan Gangguan Tidur Lainnya. Jakarta: PT Elex Media Komputindo. 
Rochman, K. L. (2010). Kesehatan Mental. Purwokerto: Fajar Media Press.

Rufaidah, E. R. (2009). Efektifitas Terapi Kognitif terhadap Penurunan Tingkat Kecemasan pada Penderita Asma di Surakarta. Tesis. Fakultas Psikologi-UGM.

Semiun, Y. (2006). Kesehatan Mental 2. Yogyakarta: Kanisius.

Singgih, D. G. (2008). Psikologi Anak: Psikologi Perkembangan Anak dan Remaja. Jakarta: PT BPK Gunung Mulia.

Socrates. (2009). Kesehatan Jiwa Pada Populasi Lanjut Usia, www.Kesimpulan.Co.Cc, Di Akses 4 Januari 2019

Soedomo, A. (2003). Demensia Pada Lansia Dan Penatalaksanaannya: Simposium Peningkatan Kualitas Hidup Lansia. Surakarta, FK UNS. Soehartono, I. (1995). Metode Penelitian Sosial. Bandung: Remaja Rosdakarya.

Sponholz, K. (2002). Effects of mental-skills training on collegiate divers' performance And perception of success. Master of Science in Education, State University of New York at Fredonia. itian. Surabaya: Unesa University Press-2012

Stuart, G. W \& Sunden, SJ. (1998). Buku Saku Keperwatan Jiwa. Jakarta: EGC.

Stuart, G. W. (2013). Buku Saku Keperawatan Kesehatan Jiwa. Jakarta: EGC.

Sugiyono. (2007). Statistik untuk penelitian. Bandung: Alfabeta.

Sundari, S. (2004). Kearah Memahami Kesehatan Mental. Yogyakarta: PPB FIP UNY.

Sundari, S. (2004). Kesehatan Mental dalam Kehidupan. Penerbit Rineka Cipta Jakarta. 
Suryabrata, S. (2005). Alat Ukur Psikologis. Ed. III. Yogyakarta: Andi Offset.

Swasti, K. G., Helena, N. C. D., \& Pujasari, H. (2013). Penurunan Ansietas dalam Menghadapi Ujian Nasional pada Siswa Kelas XII SMAN X Melalui Pemberian Terapi Suportif. Jurnal Keperawatan Soedirman (The Soedirman Journal of Nursing), 8, (2), 127-142. http://www.jks.fikes.unsoed.ac.id/index.php/jks/issue/view/112

Taisir. (2008). Potensi Masalah Lansia Dan Solusi, Taisir1@Yahoo.Com, Diakses 4 Januari 2019

Thorson, J. A., \& Powell, F. (1993). Relationships of death anxiety and sense of humor. Psychological Reports, 72, (3),1364-1366. https://doi.org/10.2466/pr0.1993.72.3c.1364

Tomb, D. A. (2004). Hos Psychiatry, 6th Edition, Lippincott Williams \& Wilkins Inc, USA.

Utami, M. S. C. (1996). Kreativitas dan Keberbakatan. Jakarta: Gramedia.

Utari, D. R. (1980). Studi Pendahuluan TMAS Sebagai Alat Ukur Kecemasan. Yogyakarta: Konggres I Ilmu Psikologi Dan ISPSI

Vrisaba, R. (2002). Mengapa Anda Sulit Tidur. Bandung: Pionir Jaya.

Willis, S. (2005). Remaja \& Masalahnya. Bandung: Alfabeta.

Wiramihardja, S. (2005). Pengantar Psikologi Abnormal. Bandung: Refika Aditama

Wiramihardja, S. A. (2005). Pengantar Psikologi Klinis. Bandung: PT. Refika Aditama.

Yovetick., Dale., \& Hudak. (1990). An investigation of worry and sense of humor. The Journal of Psychology, 136, 657-662. https://www.tandfonline.com/toc/vjrl20/136/6

Yusuf, S. (2009). Mental Hygine: Terapi Psikopiritual untuk Hidup Sehat Berkualitas. Bandung: Maestro. 
Retna Febri Arifiati, Endang Sri Wahyuni

Zulkarnain., \& Novliadi, F. (2009). Sense of Humor dan Kecemasan Menghadapi Ujian di Kalangan Mahasiswa. Majalah Kedokteran $\begin{array}{lll}\text { Nusantara, } & 42, & \text { (1), }\end{array}$ https://www.researchgate.net/publication/237841775 